Kıroğlu, K., Tut, E., Aydoğmuş, M. ve Torun, N. (2021). Ara tatilin okuma yazma öğrenme sürecine yansımaları. Ana Dili Eğitimi Dergisi, 9(2), 451-469.

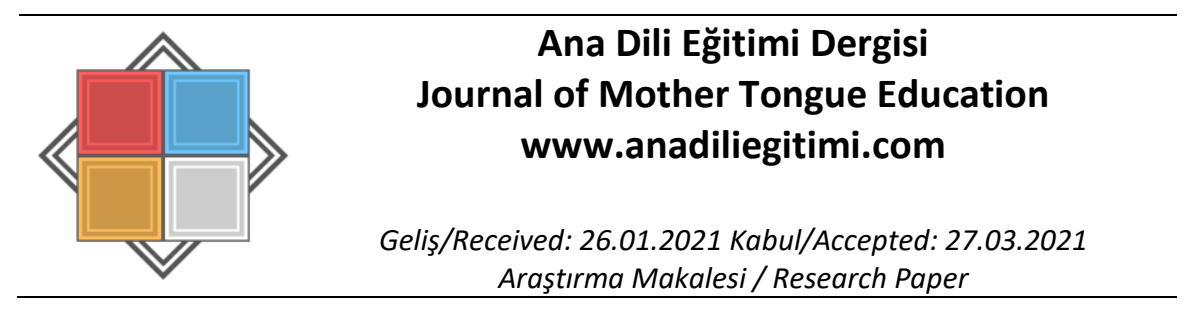

\title{
Ara Tatilin Okuma Yazma Öğrenme Sürecine Yansımaları
}

\author{
Kasım KIROĞLU* \\ Edip TUT ${ }^{* *}$ \\ Mücahit AYDOĞMUŞ \\ Nurdan TORUN $N^{* * *}$
}

Öz

Bu çalışmanın amacı, ara tatilin ilk okuma yazma öğrenme sürecine yansımalarını öğretmen görüşleri çerçevesinde ortaya koymaktır. Araştırmada temel nitel araştırma deseni kullanılımıştır. Araştırmanın çalışma grubunu 2019-2020 eğitim-öğretim yılında Samsun ilinin Atakum ilçesine bağlı ilkokullarda görev yapan 24 sınıf öğretmeni oluşturmaktadır. Çalışma grubu maksimum çeşitlilik örneklemesi yoluyla belirlenmiş ve Atakum'daki her ilkokuldan bir sınıf öğretmeni çalışmaya dahil edilmiştir. Araştırmada veriler, yarı yapılandırılmış görüşme formu aracılı̆ııyla ve öğretmenlerle yapılan yüz yüze görüşmeler neticesinde elde edilmiştir. Elde edilen veriler içerik analizi yöntemiyle analiz edilmiştir. Araştırmada, öğretmenlerin görüşlerine göre ara tatilin öğrencilere duyuşsal boyutta etki ettiği ve bu durumun öğrencilerin ilk okuma yazma öğrenme süreçlerini etkilediği sonuçlarına ulaşılmıştır. Ayrıca ara tatilin ilk okuma yazma öğrenme sürecine etki etmesinde; okul tipi, ebeveyn desteği, teknolojik imkanlar, okul öncesi eğitim, tatil öncesi işlenen ses grubu sayısı gibi birtakım etmenlerin rol oynadığı sonuçlarına ulaşılmıştır.

Anahtar Kelimeler: Ara tatil, ilkokul, okuma, yazma, ilk okuma yazma öğretimi

\section{The Effects of Midterm Break on the Process of Learning Literacy Skills \\ Abstract}

The purpose of this study was to determine the effects of the midterm break on the process of learning basic literacy skills based on teachers' opinions. The study employed the basic qualitative research design. The study group consisted of 24 classroom teachers working at primary schools in the Atakum district of the province of Samsun in the 2019-2020 academic year. The sample was formed through maximum variation sampling and one teacher was selected from each primary school. The data were collected during interviews with teachers using a semi-structured interview form. The collected data were analyzed through content analysis. The results showed that midterm breaks affected students' literacy skills affectively and that this repercussion affected the process of basic literacy learning in the students. In addition, it was found that a number of factors such as school type, parental support, technological resources, preschool education, and the number of letter clusters taught at school before the semester holiday played a key role in the process of learning basic literacy skills during the midterm break.

Keywords: Midterm break, elementary school, reading, writing, teaching literacy

\footnotetext{
* Doç. Dr., Ondokuz Mayıs Üniversitesi, Eğitim Fakültesi, Temel Eğitim Bölümü, Samsun, november@omu.edu.tr, ORCID: orcid.org/0000-0001-5711-9182

${ }^{* *}$ Arş. Gör., Ondokuz Mayıs Üniversitesi, Eğitim Fakültesi, Temel Eğitim Bölümü, Samsun, ediptut@hotmail.com, ORCID: orcid.org/0000-0003-2191-6539

*** Arş. Gör., Ondokuz Mayıs Üniversitesi, Eğitim Fakültesi, Temel Eğitim Bölümü, Samsun, mucahit.aydogmus@omu.edu.tr, ORCID: orcid.org/0000-0002-1418-1100

**** Yüksek Lisans Öğrencisi, Ondokuz Mayıs Üniversitesi, Eğitim Fakültesi, Temel Eğitim Bölümü, Samsun, torunanur@gmail.com, ORCID: orcid.org/0000-0002-9783-5260
} 


\section{Giriş}

Dil gelişimi dinleme, konuşma, okuma ve yazma becerilerini içeren bir süreçtir. Doğumdan önce başlayan dil gelişim süreci (Güneş, 2010) hayat boyu devam etmektedir. Çocuğun okula başlamasına kadar geçen süreçte sistemli olmayan bir şekilde dinleme ve konuşma becerileri aile ve çevrenin etkisiyle gelişim gösterirken çocuğun okula başlamasıyla birlikte bu süreç sistemli hale gelir ve okuma ve yazma becerileri de gelişmeye başlar (Babayiğit, 2016). Dolayısıyla okula başlama çocuğun dil gelişimi için kritik bir dönemdir ve ailesi ve çevresinden ana dilini öğrenerek okula başlayan çocuk, ilkokulda ana dilini kurallarıyla birlikte sistematik bir şekilde öğrenmeye başlar (Gözüküçük, 2017). Bu dönemde çocuğun kazandığı dil becerilerinin yaşam boyu devam eden dil gelişimi için büyük önem taşıdığı söylenebilir. Çünkü hayatın her alanında kullanmak zorunda olduğu dil becerilerinin temelleri ilkokulda atılmaktadır. Dolayısıyla çocuğun iyi bir okuryazar olmasının temelinde ilkokulda kazandığı okuma ve yazma becerilerinin etkili olduğu söylenebilir. Okuryazarlığın kapsamı geçmişten günümüze genişlemiş ve fen okuryazarlı̆̆ı, matematik okuryazarlığı gibi kavramlar literatürde yerini almıştır. Okuryazarlık türleri ne kadar çeşitli olursa olsun tamamının temelinde okuma ve yazma bulunmaktadır (Aslan ve Altunova, 2019).

Okuma; okuyucu ve yazar arasında aktif ve etkili iletişimi gerekli kılan, dinamik bir anlam kurma sürecidir ve bireyin yeni kelimeler öğrenerek, yeni anlayışlar kazanarak, yaratıcılı̆ıııı geliştirerek ufkunu genişletir ve derinleştirir (Akyol, 2020). Okuma; ön bilgilerden hareketle metindeki bilgileri bütünleştirerek yeni anlamlar oluşturma süreci (Güneş, 2009), metindeki duygu, düşünce ve iletileri anlamak (Karatay, 2018), ses ve görme yetileriyle algılanan işaret ve sembollerin beyinde yorumlanıp değerlendirilmesi ve anlama ulaştırılması (Kurudayıoğlu, 2011) ve yazılı bir metni görüp kendine özgü bir biçimde anlamlandırma (ArıCl, 2018) olarak tanımlanmaktadır. Tüm bu tanımlardan anlaşılacağı üzere okumanın temelinde anlama ve anlamlandırma yatmaktadır. Yazma ise düşünceleri ifade edebilmek için gerekli olan sembol ve işaretleri motorsal olarak üretebilmek (Akyol, 2011), amaçlı olarak üstbilişsel izleme ve kontrol doğrultusunda düşünce üreterek sembolik olarak ifade etmek (Karadağ, 2017) ve duygu, düşünce ve istekleri bazı sembolik şekil ve çizimlerle, kurallara uygun biçimde anlatmak (Hacker, Keener ve Kircher, 2009) olarak tanımlanmaktadır. Bireyler için yazma; hayali dünyalar oluşturmak, hikâyeler anlatmak, bilgiyi paylaşmak, kendini keşfetmek, yalnızlıkla baş etmek ve deneyimleri kayıt altına almak için önemlidir (Graham, Gillespie ve McKeown, 2013). Okuma ve yazma birlikte düşünüldüğünde; okumanın, sembollerle ifade edilenleri anlamayı, yazmanın ise anlatılmak istenenleri sembollerle ifade etmeyi karşıladığı söylenebilir (Kasten ve Yıldırım, 2013).

Okuma ve yazma becerileri birbirinden ayrı düşünülmemelidir. Çünkü okumanın amacı anlama, yazmanın amacı ise anlatmadır. Okuma ve yazma; hazırlık, gözden geçirme, tekrar, düzenleme, özetleme gibi karmaşık bilişsel süreçleri ve aşamaları içeren, bilişsel, duyuşsal ve psikomotor becerilerin işe koşulduğu süreçlerdir. Bireylerin iletişim süreçlerinde, hayatları boyunca karşılaştıkları farklı durumları anlayabilmeleri ve kendilerini iyi anlatabilmeleri için bu iki becerinin okul çağında kazandırılması kritik önem taşımaktadır. Ayrıca 6-8 yaş, çocukların okuma kültürü kazanmalarında en belirleyici dönemlerden biridir ve bu dönemde okuma ve yazma becerisini edinen çocuklar karşılaştıkları metinlerle kendilerine yeni bir yaşam alanı yaratırlar (Ince Samur, 2017). Buradan hareketle; bireylere okuma ve yazma becerilerinin kazandırılmasında planlı, programlı ve sistematik bir öğretimin yapıldığı bu kritik sürecin ilk okuma yazma öğretimi süreci olduğu söylenebilir.

Illk okuma yazma öğretimi; ilkokul birinci sınıfta başlayan, aile desteğiyle öğretmen rehberliğinde planlı ve programlı bir şekilde gerçekleştirilen, çocuğa okuma ve yazma becerisi kazandırma süreci olarak tanımlanmaktadır (Baş, 2006). Bu süreçte amaç; okuma ve yazmayı çocuğun seviyesine uygun olarak, çeşitli araç gereçler kullanarak, verimli ve etkili bir şekilde öğretmektir (Dedeli, 2008). İlk okuma yazma öğretimi yalnızca temel düzeyde okuma ve yazma becerilerini kazandırmayı değil düşünme, anlama, sıralama, sınıflama, sorgulama, ilişki kurma, analiz sentez yapma ve değerlendirme gibi zihinsel becerileri geliştirmeyi (MEB, 2019), Türk dilini sevdirmeyi, etkili iletişim becerileri kazandırmayı, Türkçeyi bilinçli, doğru ve etkili kullanmayı, okuma yazma sevgisi ve alışkanlığı kazandırmayı ve kelime hazinesini geliştirmeyi de amaçlamaktadır (Akyol, 2020). ilk okuma 
yazma öğretimi diğer dersler ve hayatın tüm alanları için de kilit bir rol oynamaktadır (Gözüküçük, 2017). Çünkü çocuklar diğer derslerde ve yaşamlarının birçok alanında metinlerle (görsel, yazılı, sözlü vb.) karşı karşıya gelmektedirler ve bu metinleri anlamaları ve iç dünyalarını, oluşturdukları metinlerle etkili bir şekilde anlatmaları, okuma ve yazma becerilerinin niteliği ile doğrudan ilgilidir. Bu nedenle ilk okuma yazma öğretimi etkinliklerinin güçlü ve etkili program, strateji, yöntem ve tekniklerle uygulanması gereklidir.

İlk okuma yazmayı öğrenme sürecinde takvim yaşı, cinsiyet, sağlık sorunları, beyin başatlığı, genel zekâ, zihinsel düşünme, özel bilişsel problemler, görsel ve işitsel ayrım, ilişkilendirici öğrenme, dikkat, sözel dil gelişimi ve aile gibi okumaya hazır oluşla ilgili faktörler; oturuş, kas gelişimi, yönler, el tercihi, boşluklar, harf biçimi, kalem ve kalem tutma, kâğıt ve kâğıdın pozisyonu, yazma hızı ve çizgi takibi gibi yazmayı etkileyen faktörler bulunmaktadır (Akyol, 2020). Tutal ve Oral (2015), okula başlama yaşının ilk okuma yazma öğrenmede etkili olabileceğini; okula küçük yaşlarda başlayan öğrencilerin büyük yaştakilere göre birtakım problemler yaşayabileceğini ifade etmektedir. Durna'nın (2014) araştırmasına göre de okula küçük yaşta başlayan öğrencilerin daha büyük başlayanlara göre ilk okuma yazma kazanımlarına ulaşma düzeylerinin çok daha az olduğu görülmektedir. Benzer şekilde Ekici Calın'ın (2019) araştırması önbilgilerin, okula başlama yaşının, ebeveyn desteğinin ve sınıf mevcudunun ilk okuma yazma öğretiminde etkili olduğunu göstermektedir. Ayrıca Park'ın (2008) araştırması, ebeveynleri ilk okuma yazmayı öğrenme sürecine sık katılan çocukların daha az katılanlara göre okumada daha başarılı olduğunu ve evdeki kitap sayısı ve ebeveynlerin okuma yazma aktivitelerine karşı tutumlarının çocukların okuma başarılarında etkili olduğunu göstermektedir. Yine Obalar'ın (2009) araştırmasına göre ebeveynlerin eğitim düzeyi, ekonomik durum ve sosyokültürel çevre, çocukların okuma yazma başarılarında önemli bir yere sahiptir. Bununla birlikte ilk okuma yazma öğretiminde niteliği belirleyen en önemli ögenin kullanılan yöntem olduğu (Tosunoğlu, 2006) ve öğretmenin bu süreçte büyük bir rol oynadığı (Kabaş, 2020) söylenebilir. Dolayısıyla ilk okuma yazma öğretiminde öğrenci başarısını etkileyen faktörler genel olarak; öğrenci, öğretmen, aile, çevre, okul ve program olarak sıralanabilir (Anras, 2019). Bu etkenlerin yanı sıra eğitim sürecindeki tatillerin ilk okuma ve yazma sürecine etki edebileceği düşünülmektedir. Nitekim araştırmalar; dönemin yorgunluğunu giderme, dinlenme ve rahatlama amaçlarıyla eğitime verilen aralarda öğrencilerin birtakım öğrenme kayıpları yaşadıklarını göstermektedir (Arı, 2005; Şahin, 2004; Şen, 2009). Bazı araştırmalarda ise tatillerin; öğrencilerin aileleriyle güzel zaman geçirmelerine, dinlenmelerine, sınav stresinden uzaklaşmalarına imkân tanıdığını göstermektedir (Kaya, 2020).

PISA ve PIRLS gibi uluslararası sınavlarda okuma alanında başarı gösteren Estonya, Kanada, Finlandiya, İrlanda, Rusya, Singapur gibi ülkeler başta olmak üzere birçok ülkede resmi ve dini tatiller ile yaz tatili ve sömestr tatilleri dışında her dönem birer hafta olmak üzere ara tatil uygulaması gerçekleştirilmektedir. Türkiye'de ise ilk defa 2019-2020 eğitim öğretim yılında, yaz tatili iki hafta kısaltılarak kasım ve nisan aylarında birer hafta olmak üzere ara tatil uygulaması başlamıştır (Burç ve Karakuyu, 2020). 30827 sayılı Resmî Gazete'de yayımlanan Millî Eğitim Bakanlığı Okul Öncesi Eğitim ve Illköğretim Kurumları Yönetmeliği'ne 'ara tatil' ibaresi eklenmiş ve 'hafta sonu' ibaresi, 'hafta sonu tatili, ara tatil' olarak değiştirilmiştir (Resmî Gazete, 2019). Uluslararası literatürde ara tatil uygulamalarıyla ilgili bilimsel çalışmalara rastlanmazken Türkiye'de ara tatil uygulamasını konu alan araştırmaların öğrencilerin ara tatil uygulaması ile ilgili değerlendirmeleri (Kaya, 2020) ve ara tatil uygulamasına ilişkin öğretmenlerin görüşlerine (Burç ve Karakuyu, 2020; Doğan, 2020) odaklandığı görülmektedir. Bu araştırma ise ara tatil uygulamasının ilk okuma yazma öğretimi sürecine yansımalarını incelemeyi amaçlamaktadır. Bu araştırmanın; doğrudan ilk okuma yazma öğretimi sürecine odaklanması nedeniyle önemli olduğu ve alandaki bu boşluğu dolduracağı düşünülmektedir. Ayrıca kritik öneme sahip olan birinci sınıfta, 9 günlük ara tatil uygulamasının ilk okuma yazma öğretimi sürecinde önemli bir etkiye sahip olabileceği ve bu sürecin öğretmen görüşleri çerçevesinde değerlendirilmesinin alana katkı sağlayacağı düşünülmektedir. Bu araştırma sonuçlarının sınıf öğretmenlerine ara tatile hazırlık ve tatil sonrası eğitim öğretim faaliyetlerinin planlanması hususunda önemli dönütler sağlayacağı düşünülmektedir. Buradan hareketle bu araştırmada şu sorulara cevap aranmaktadır:

- Ara tatilin okumayı öğrenme sürecine yansımalarına yönelik öğretmen görüşleri nelerdir? 
- Ara tatilin yazmayı öğrenme sürecine yansımalarına yönelik öğretmen görüşleri nelerdir?

- Ara tatilin okumayı öğrenme sürecine yansımalarında rol oynayan etmenler nelerdir?

\section{Araştırmanın Modeli}

Yöntem

Bu çalışmada nitel araştırma yaklaşımlarından temel nitel araştırma deseni kullanılmıştır. Temel nitel araştırmaların amacı bireylerin hayatlarını ve deneyimlerini nasıl kavradıklarını, onlardan nasıl sonuçlar çıkardıklarını kendi görüşleri çerçevesinde anlamak ve ortaya koymaktır (Merriam, 2013). Temel nitel araştırma, katılımcıların belirli bir olay veya durumla ilgili deneyimlerini hem olgu ya da durumun hem de ortamın zengin bir şekilde betimlenmesiyle ortaya koymaya çalışır (Creswell, 2011; Lodico, Spaulding ve Voegtle, 2010). Bu tür araştırmalarda hedef; bir fenomeni, süreci veya belirli bir bakış açııını ilgili kişilerin perspektifinden anlamaktır (Ary, Cheser Jaobs, Sorensen Irvine ve Walker, 2019). Bu sayede temel nitel araştırmalar herhangi bir olay veya durumla ilgili kişilerin "çoklu veya bireysel gerçekliklerini" anlamaya yardımcı olur (Pickard, 2012). Dolayısıyla bu desenin, eğitim sistemimizde yeni olan ara tatil uygulamasının ilk okuma yazma öğretimi sürecine etkisini öğretmen görüşlerinden yola çıkarak ortaya koymada uygun olduğu düşünülmektedir.

\section{Çalışma Grubu}

$\mathrm{Bu}$ araştırmanın çalışma grubunun belirlenmesinde amaçlı örnekleme yöntemlerinden maksimum çeşitlilik örneklemesi kullanılmıştır. Heterojenite örneklemi olarak da adlandırılan maksimum çeşitlilik örneklemi bir ortamın veya fenomenin ortak boyutlarını veya temel deneyimlerini yakalamak adına değerlidir (Patton, 2014) ve nitel araştırmalarda farklılaşabilen bakış açılarını bir araya getirmesinden dolayı kullanışıdır (Yıldırım ve Şimşek, 2018). Bu araştırmada da farklı bakış açılarını bir araya getirmek hedeflenmiştir. Araştırma verilerinin toplandığı 2019-2020 eğitim öğretim yılında Samsun ili, Atakum İlçe Milli Eğitim Müdürlüğü’ne bağlı 24 ilkokul bulunmaktadır. Araştırmanın çalışma grubunu her ilkokuldan bir öğretmen olmak üzere toplam 24 sınıf öğretmeni oluşturmaktadır. Katılımcıların belirlenmesinde gönüllülük esas alınmıştır. Bu öğretmenlerden 22'si birinci sınıf, 2'si ise birleştirilmiş sınıflarda görev yapmaktadır. Bu sayede okul iklimi ve şartlarından kaynaklanabilecek görüş farklııklarının birlikte değerlendirilmesi sağlanmıştır. Ayrıca cinsiyetin ve mesleki kıdemin, dolayısıyla tecrübenin, bu görüşlere etki edebileceği düşünüldüğünden kıdem ve cinsiyet açısından da çeşitlilik sağlanmaya çalışıımıştır. Çalışma grubunu oluşturan öğretmenlerin çalışma süreleri 4 ile 39 yıl arasında değişmektedir. Ayrıca öğretmenlerden 14'ü erkek 10'u kadındır. Öğretmenlerin çalıştıkları okullar bulunduğu bölge itibarıyla köy okulu ve merkezi okul şeklinde çeşitlilik göstermekte ve sınıf mevcutları 3 ile 42 öğrenci arasında değişmektedir. Ayrıca çalışma grubunda birleştirilmiş sınıflarda görev yapan iki öğretmen de yer almaktadır. Araştırma bulgularının sunumunda öğretmenlerin kişisel bilgilerine yer verilmemesi adına takma isimler kullanılmıştır.

\section{Veri Toplama Araçları}

Araştırmada veriler, sözlü iletişim yoluyla veri toplama tekniği olarak tanımlanan (Karasar, 2015) "görüşme" yöntemiyle toplanmıştır. Amacı, diğer insanların bakış açılarına ulaşmak olan görüşme yöntemi gözlem yoluyla elde edilemeyen verilerin toplanmasında etkili bir yöntemdir (Patton, 2014). Bu araştırmada yarı yapılandırılmış görüşme esas alınmıştır. Bu doğrultuda araştırmacılar tarafından yarı yapılandırılmış bir görüşme formu geliştirilmiş ve veriler bu form yardımıyla toplanmıştır. Görüşme formu geliştirilirken, öncelikle bir soru havuzu oluşturulmuştur. Soru havuzundan, öğretmenlerle gerçekleştirilecek görüşmelerde kullanılacak soruların belirlenmesinde dört araştırmacının ortak görüşü esas alınmıştır. Daha sonra nitel araştırma yaklaşımlarına hâkim bir öğretim üyesinin görüşleri alınarak görüşme formuna son hali verilmiştir. Görüşme formunun okunabilirliği ve anlaşılabilirliğinin test edilmesi amacıyla çalışma grubu dışında, birinci sınıf okutan bir öğretmenle görüşülerek form üzerinde gerekli düzeltmeler yapılmıştır. Görüşme formu "Ara tatil öğrencilerinizin okumayı öğrenme sürecini nasıl etkiledi?” ve "Ara tatil 
öğrencilerinizin yazmayı öğrenme sürecini nasıl etkiledi?" olmak üzere iki temel soru ve dörder sonda sorudan oluşmaktadır.

\section{Verilerin Toplanması}

Nitel araştırmalarda yapılan görüşmelerin uzun soluklu olması, mülakata taraf olan kişiler arasındaki güven bağının oluşması ve daha rahat bir ortam oluşması açısından önem arz etmektedir (Patton, 2014; Yıldırım ve şimşek, 2018). Bu araştırmada da çalışma grubundaki öğretmenlerle yapılan ilk görüşmeler tanışma ve çalışmayı tanıtma çerçevesinde gerçekleştirilmiş ve öğretmenlerin, veri toplama sürecinde daha rahat olmaları sağlanmaya çalışılmıştır. Daha sonraki görüşmede veri toplama süreci başlatılış ve veri toplama sürecinden sonra da öğretmenlerle görüşülüp verilere ilişkin katılımcı teyidi alınmıştır. Toplamda her bir öğretmenle üçer kez görüşme yapıımıştır. Araştırmanın verileri Atakum illçe Milli Eğitim Müdürlüğü’nden alınan izin doğrultusunda 2019 yılı aralık ayında toplanmıştır. Öğretmenlerle yapılan ilk görüşmeler 15-20 dakika, asıl veri toplama işleminin gerçekleştirildiği ikinci görüşmeler 30-45 dakika son görüşmeler ise ortalama 10 dakika sürmüştür. Görüşmelerin tamamı ses kayıt cihazı ile kayıt altına alınmış ve daha sonra yazıya aktarılarak analize hazır hale getirilmiştir.

\section{Verilerin Analizi}

Öğretmenlerle yapılan görüşmelerden elde edilen veriler içerik analizi yöntemiyle analiz edilmiştir. İçerik analizi, hacimli bir nitel veriyi temel tutarlılıkları ve anlamları belirlemeye yönelik veri indirgeme ve anlamlandırma çabasını ifade eder (Patton, 2014). Iç̧erik analizinde yapılan işlem, birbirine benzeyen verileri belirli kavramlar ve temalar çerçevesinde bir araya getirmek ve bunları okuyucunun anlayacağı bir şekilde düzenleyerek yorumlamaktır (Yıldııım ve Şimşek, 2018). Bu araştırmada da elde edilen veriler birinci aşamada kodlanmış ve ikinci aşamada ise kodlar Saldana (2019) tarafından "oluşturulan veri parçacıklarını gruplandırarak daha az sayıda kavram veya temaya dönüştürme yolu" olarak tanımlanan "örüntü kodlama" yöntemi ile gruplandırılmıştır. Bu sayede veriler belirli temalar altında bir araya getirilmiş ve yorumlanmıştır.

\section{Geçerlik ve Güvenirlik}

İçerik analizinin geçerlik ve güvenirliğini sağlamak adına dikkat edilmesi gereken en önemli husus farklı kodlayıcıların aynı sonuçlara ulaşmasını sağlayacak nitelikte açık ve net temaların oluşturulmasıdır (Silverman, 2018). Bu araştırmada, analizin geçerlik ve güvenirliğini artırmak adına kodlama ve oluşturulan temalar dört araştırmacı tarafından kontrol edilmiş ve araştırmacı bağlamında çeşitlilik sağlanmıştır. Dört araştırmacı verileri ayrı ayrı kodlamış ve analizde görüş birliğine varılana dek araştırmacılar tarafından görüşmeler gerçekleştirilmiştir. Ayrıca Miles ve Huberman'ın (1994) önermiş olduğu güvenirlik katsayısı hesaplama formülü kullanılmıştır. Miles ve Huberman'a (1994) göre en az \%80 olması gereken araştırmacılar arası uyum, bu araştırmada \%92 olarak hesaplanmıştır. Analiz sonucunda üç tema ve 12 kategori oluşmuş, kodların kategorileştirilmesinde ilk iki temada araştırmacılar arasında tam bir görüş birliği sağlanmış, üçüncü temada ise var olan kodlar görüş birliği esas alınarak kategorileştirilmiştir. Bununla birlikte Türkçe öğretimi alanında uzman ve nitel araştırma yaklaşımlarına hâkim olan bir öğretim üyesinden veri analizine yönelik görüş alınmış ve bu sayede uzman teyidi sağlanmıştır. Bu araştırma; Atakum illçe Milli Eğitim Müdürlüğü’ne bağı 24 okul, bu okulların her birinden seçilen birer sınıf öğretmeni, görüşme formunda yer alan sorular ve bu sorular çerçevesinde toplanan verilerle sınırlıdır.

\section{Araştırma ve Yayın Etiği}

Bu çalışmada "Yükseköğretim Kurumları Bilimsel Araştırma ve Yayın Etiği Yönergesi" kapsamında uyulması belirtilen tüm kurallara uyulmuştur. Yönergenin ikinci bölümü olan "Bilimsel Araştırma ve Yayın Etiğine Aykırı Eylemler" başlığı altında belirtilen eylemlerden hiçbiri gerçekleştirilmemiştir. 


\section{Etik Kurul İzni}

Kurul adı = Ondokuz Mayıs Üniversitesi Sosyal ve Beşerî Bilimler Etik Kurulu

Karar tarihi $=29.11 .2019$

Belge sayı numarası $=2019-381$

\section{Bulgular}

Bulgular genel anlamda ara tatilin okumayı öğrenme ve yazmayı öğrenme sürecine etkisi ile ilgili görüşleri ve ara tatilin okuma yazmayı öğrenme sürecine yansımalarında etkili olan etmenler olarak üç temel başlık altında sunulmaktadır.

\section{Öğretmenlerin Ara Tatilin Okumayı Öğrenme Sürecine Etkisi ile IIIgili Görüşleri}

Öğretmen görüşlerine göre ara tatilin, okumayı öğrenme sürecine olumlu ve olumsuz etkilerinin olduğu görülmektedir. Bu tema kapsamındaki bulgular "olumlu etkilere yönelik görüşler" ve "olumsuz etkilere yönelik görüşler" kategorileri altında sunulmuştur.

\section{Olumlu Etkilere Yönelik Görüşler}

Öğretmenlerin büyük çoğunluğu ara tatilin öğrencilerin okumayı öğrenme sürecine olumlu etkisinin olduğunu belirtmiştir. Öğretmenlere göre ara tatil öğrencileri duyuşsal boyutta olumlu etkilemiş ve bu olumlu etki, öğrencilerin okumayı öğrenme sürecine de yansımıştır. Öğretmenlerden bazılarının bu hususla ilgili ifadeleri aşağıdaki gibidir:

Ufuk: Çocuklar bu süreçte (ara tatil öncesi) bunalmışlardı, dönem yoğun geçiyordu. Onlar için dinlendirici oldu. Öğrenmeye daha istekli geldiler. Yaptıkları çalışmalardan dolayı da unutmadılar ögrendiklerini. Hepsi mutluydu ve bu sebeple de daha iyi ilerledik.

Osman: Onlar için bir farklılık oldu aslında. Bizim için de biraz enerji depolama fırsatı oldu. Döndüklerinde beni ve okulu özlediklerini gördüm. Bu benim için ara tatilin en büyük olumlu yanı oldu. Dönüşte daha bir şevkle ve daha hızlı ilerledik.

Ömer: Ara tatilin unutma gibi olumsuz bir etkisini görmedim. Öğrenciler motive geldiler, daha dinlenmişlerdi. Onun katkısı olduğunu düşünüyorum öğrenmelerine.

Öğretmenlere göre birinci sınıfın ilk zamanları öğrencilerin uyum sorunu yaşadığı zamanlardır. Bu sebeple ara tatilin öğrencilerin okula uyumunu kolaylaştırma konusunda katkı sağladığı ve bu durumun okuma yazmayı öğrenmelerine de olumlu etkisinin olduğu görüşleri yer almaktadır. Bu görüşler aşağıdaki gibi örneklendirilebilir:

Gökhan: Ara tatile sadece akademik olarak bakmamamız lazım. Birinci sınıf çocukları özellikle ilk haftalarda uyum konusunda zorluk çekebiliyor. Okul öncesi eğitimde bir zorunluluk, ders veya teneffüs saati diye bir şey yok. Öncelikle bunlara alışmaya çalışıyorlar. Tabii sonrasında çizgi çalışmaları ve harf çalışmalarıla başlıyoruz. Önceki dönemlerde çocuk ocak-şubat aylarına kadar bayağı bunalıyordu, derse olan ilgileri azalıyor, performansları düşüyordu. Bu yüzden ara tatilde benim çocuklarımda gerileme olmadı, aksine ilerleme oldu. Tatil öncesi 5-6 harf vermiştik. Sürecin başında olmamıza rağmen çocuklar tatilden sonra daha istekli oldular.

Ara tatilin okumayı öğrenme sürecine olumlu başka bir etkisi olarak öğretmenler, sınıf düzeyine göre okumayı öğrenmede geride kalan öğrencilerin bu süreçte tekrar yapma ve eksiklerini kapatma fırsatı bulduğunu belirtmişlerdir. Örneğin Aslı, bu süreçte sınıf seviyesinden geride olan öğrencilerinin kendilerini toparladığını belirtmiştir ve bu sebeple ara tatilin olduğu dönemin olmadığı döneme oranla daha verimli geçtiğini ifade etmiştir. Yasin, "Birinci sınıfta bir gün devamsızık bile kayıp oluyor. Devamsızlık yapan ögrrencilerde bu süreç eksiklikleri kapatma adına bir fırsat oldu." diyerek bu görüşü desteklemiştir. Ali de geride kalan öğrencilerinin aileler tarafından bu süreçte özel olarak çalıştırılmasını istemiş ve benzer ifadelerle ara tatilin bu öğrenciler için bir avantaj olduğunu belirtmiştir. Tülay ise öğrencilerin, okumayı öğrenmede geride kalmasının stres kaynaklı olduğunu belirtmiş ve ara tatilin bu öğrencilere etkisini şu şekilde ifade etmiştir:

"Çocuklar bu süreçte dinlendi. Rahat kafayla okuma yapma imkânı buldu. Diğer şekilde strese giriyor çocuk ya okuyamazsam ya yetiştiremezsem diye. Bu süreçte öğrencilerim daha rahat oldu ve bu şekilde okuma ilgilerini de çekti. Özellikle geride kalan öğrencilerime yaradı bu tatil. Çocuk bir geldi 
baktık ki çok rahatlamış ve okumada da ilerleme kaydetmiş. Stresten kurtulmuş en temelde, akran baskısından da kurtulmuş. Okulda iş gibi görülüyor ama bu süreçte evde olmak daha rahat geçirmelerine olanak sağlıyor."

\section{Olumsuz Etkilere Yönelik Görüşler}

Ara tatilin okumayı öğrenme sürecine olumsuz etkileri olduğunu belirten öğretmenler de yer almaktadır. Ara tatilin olumsuz etkilerinin genel anlamda öğrencilerin gevşemesi ve rehavete kapılması görüşleri etrafında toplandığı söylenebilir. Örneğin Arzu, ara tatilin zamanlamasının uygun olmadığı belirtmiş ve bunun öğrencilerinin okumayı öğrenme sürecine olumsuz etkilerini şu şekilde ifade etmiştir:

“Okumayı öğrenme sürecine olumsuz etki ettiğini düşünüyorum. Tatil tam kasımın ortasına denk geldi. Dolayısıyla tam böyle hızlanmaya başlamışken, çocuklar artık okuma yazmanın mantığını kavramaya başlamışken bir haftalık kocaman bir ara giriyor. Tekrar toparlaması zor oldu. Hızlanan çocuklar yavaşladı, yavaş giden çocuklar iyice durdu."

Bununla birlikte öğretmenlerden bazıları ara tatil sürecinin okumayı öğrenme sürecini yavaşlattığını ve bu süreci kesintiye uğrattığını belirtmişlerdir. Konuya ilişkin görüşlerden bazıları aşağıdaki gibidir:

Yasin: Bu süreci yavaşlattığını söyleyebilirim. Tam bir rutine oturtmuşken 8-9 günlük bir tatil çocukların gevşemesine neden oluyor.

Ahmet: Olumsuz etkiledi bizi çünkü tam hızlanmıştık, haftada iki ses falan veriyorduk. Çocuklar da alışmıştı. Elleri yeni alışmıştı, sesleri heceleri birleştirmeye yeni alışmışlardı. Araya bir hafta girince ben bir gevşeme hissettim çocuklarda. Olumsuz etki sadece rehavet ve hızın kesilmesi açısından oldu.

Büşra: Ara tatil bizim okumayı öğrenme sürecimizi baltalamıştır. Kasım ayında grup harflerine gireceğimizde grup harflerine ara verdikleri için eski grupları tekrarlayıp yeni grupları veremediğimiz için öğrenme sürecini uzattı. Artı araya hafta sonu bile girse biz pazartesi günü çocuklarda yeterli randımanı göremiyoruz. Hele ki böyle bir haftalık tatil araya girdiğinde çocuklar tamamen boşalmış olarak geri geliyorlar. Tamam belki kafalarında öğrencilik stresi boşalmış oluyor ama öğrendiklerini de boşaltma gibi bir dezavantajı var. O bir hafta benim iki haftama mal oldu.

Bunlara ek olarak Ayşe de ara tatil dönüşünde öğrencilerinde isteksizlik gördüğünü ve bunun okumayı öğrenme süreçlerine olumsuz yönde etki ettiğini şu ifadelerle belirtmiştir:

Ayşe: Öğrencilerde kopmalar oldu. 9 günden sonraki çocuklardaki gevşeme beni 2-3 gün zorladı. İsteksizlik vardı çocuklarda. Annemi ara gelsin eve gideyim tarzı istekler başladı. Bazılarıyla süreci baştan başlatmak zorunda kaldım. ikinci ses grubunda ilk gruptaki motivasyon yok aradaki tatilden dolayı. Şehirdeki arkadaşlar nasıl yaptı bilmiyorum ama bizimki köy okulu olduğundan da olabilir. Birinci sınıf çocukları sürekli oyun istiyor, dersten kaçmak istiyor. Bunun üstüne tam motive olmuşken 9 günlük arada sürekli evde olmaları onları süreçten koparabiliyor.

\section{Öğretmenlerin Ara Tatilin Yazmayı Öğrenme Sürecine Etkisi ile İlgili Görüşleri}

Öğretmen görüşlerine göre ara tatilin, yazmayı öğrenme sürecine olumlu ve olumsuz etkilerinin olduğu görülmektedir. Ayrıca ara tatilin yazmayı öğrenme sürecinde önemli bir etkisinin olmadığı yönünde öğretmen görüşleri de yer almaktadır. Bu bulgular; "olumlu etkilere yönelik görüşler", "olumsuz etkilere yönelik görüşler" ve "etki etmediğine yönelik görüşler" kategorileri altında sunulmuştur.

\section{Olumlu Etkilere Yönelik Görüşler}

Çalışma grubuna dahil edilen öğretmenler arasında ara tatilin öğrencilerin yazmayı öğrenme sürecine olumlu etki ettiğini belirten öğretmenler de yer almaktadır. 17 yıllık öğretmenlik kariyerinin 15 yılında birinci sınıflara öğretmenlik yapan Mehmet ara tatilin öğrencilere duyuşsal anlamda olumlu etki ettiğini ve buna ek olarak tatilde öğrencilere yaptırdığı çalışmaların yazmayı öğrenme süreçlerine olumlu yönde etki ettiğini belirtmiştir. Mehmet'in bu konudaki ifadeleri şu şekildedir: 
Mehmet: Föy verdim onlara ve velileri bilgilendirdik. İçerik çok basitti. Mesela birinci gün annenin söylediği beş kelimeyi yaz gibi şeyler vardı. Bu çalışmalar günde en fazla beş dakikalarını alıyordu. Bu şekilde bir çalışma bizde etkili oldu. Tam böyle sıkıldıkları bir anda bir hafta dinlenmek, mevcut ortamdan uzaklaşmak onlar için pozitif oldu.

Bunun yanında Özlem, öğrencilerin ikinci harf grubuna kadar öğrenmede çaba sarf ettiklerini sonrasında ise sorun yaşamadıklarını belirtmiş ve ara tatil öncesinde ikinci harf grubunu bitirdikleri için ara tatilde öğrencilerin birçok harfi ailelerinden öğrendiğini ve ilerleme kaydettiklerini şu ifadelerle ortaya koymuştur:

Özlem: Yazmaya bir olumsuz etkisi olmadı. Hatta çocuklar şu an bizden önde. Şu an ben $f$ sesini veriyorum ama çocuk bir hafta önce bitirmiş onu. Soruyor evde annesine, biz de tabi veli toplantılarında onları bilgilendirdik, annesi tanıtıyor sesi ve çocuk öğreniyor. İinci grup harfleri verene kadar sıkıntı çekiyoruz zaten sonrasında çocuk sistemi çözüyor ve bu sayede sadece sesi vermeniz yetiyor. Biz de tatilden önce ikinci grubu bitirmiştik, o yüzden çocuklar sorun çekmedi hatta evde başka harfleri öğrenip gelmişler.

Ahmet ise öğrencilerin genel anlamda yazmayı sevmediklerini, yorulduklarını ve bu sebeple de ara tatilin öğrencilerinin yazmayı öğrenme sürecine olumlu etki ettiğini "Yazma açısından olumlu etkisi oldu. Çünkü çocuklar yazmayı sevmiyorlar. Elleri yoruluyor, sıkılıyorlar, kas gelişimini henüz tamamlamayanlar oluyor. $O$ açıdan biraz rahatlamışlardır çünkü tatil programını az yazı genelde okuma şeklinde planlamıştım. Sıkılganlıkları bir tık gitti." ifadeleriyle belirtmiştir.

\section{Olumsuz Etkilere Yönelik Görüşler}

Ara tatilin öğrencilerin yazmayı öğrenme sürecine olumsuz anlamda etki ettiğini belirten öğretmenlerin ifadelerinden bazıları ise şu şekildedir:

Tülay: Yazmanın okulda ve gözlem altında yapılması gerekiyor. Geldikten sonra yürüttük yazma etkinliklerimizi. Şu ana kadar geldiğimiz yerde de bir unutma falan olmadı ama bu süreçte tekrar yapamadığı için bir olumsuzluk oldu. Her beceriye yönelik etkinlik yapılmazsa unutma gerçekleşebiliyor.

Ayşe: Okuyamayan yazmayı da yapamıyor. Dolayısıyla yazma sürecine de etkisi oldu bu sürecin. Ara tatilde o kitaplardaki cümleleri okuyup yazmalarını istedim becerileri kaybolmasın diye ama okumada sıkıntı olunca çocuk gözünün önüne harfi getirip yazamıyor.

Büşra: Yazma süreci okumadan geç gelir ama okumayla direkt bağlantılıdır. O yüzden bu ara tatil süreci yazmayı da olumsuz etkiledi. Bununla ilgili ödevlendirme yapmadım çünkü bakarak yazmanın çok etkisi yok ve aileler de ilgilenmiyor. Ben dönüşte onlara bol bol dikte yaptırdım ve bir sürü hata olduğunu gördüm.

Ara tatilin öğrencilerin yazmayı öğrenme sürecine olumsuz etki etmesinde tekrar yapamama, kontrolün sağlanamaması, yetersiz aile desteği gibi faktörlerin etki ettiği görülmektedir. Öğretmenlerin yazmayı öğrenmenin okumayı öğrenmeyle doğrudan ilişkili olduğunu düşündükleri ve dolayısıyla ara tatilin okumaya olumsuz etki ettiğini düşünen öğretmenlerin yazmaya da olumsuz yansıdığını belirttikleri görülmektedir. Ayrıca ara tatilin yazmayı öğrenme sürecine olumsuz etki ettiğini düşünen öğretmenlerin bunu dikte çalışmaları esnasında fark ettiği dikkat çekmektedir. Bakarak yazma aşamasında olan sınıfların öğretmenlerinin yazmada herhangi bir sorun olmadığını belirttikleri görülmüştür.

\section{Etki Etmediğine Yönelik Görüşler}

Ara tatilin yazmayı öğrenme sürecine etkilerine yönelik veriler incelendiğinde olumlu ve olumsuz yönde etki ettiğine dair görüşlerin varlığıyla birlikte genel görüşler bu sürecin yazmayı öğrenmeye herhangi bir etkisinin olmadığı yönündedir. Bu duruma yönelik bazı ifadeler aşağıdaki gibidir:

Aynur: Okuyan öğrenci sonrasında zaten yazıyor. O yüzden yazmayı etkilemedi. Çocuk zaten belirli çizgi çalışmalarını yapıyorsa bedensel olarak hazırlanmış oluyor. Harfleri de tanıyınca yazıyor.

Yasin: Yazmada etkisi olduğunu düşünmüyorum. Yazma okuma gibi kolay kaybedilen bir beceri değil. Bu süreçte zaten öğrendiğimiz harfleri genelde bakarak yazıyoruz. 
Arzu: Yazma bir beceri meselesi sonuçta. Ha diktede bir başarı düşüklügü olmuş olabilir ama harf öğretildiği zaman yazma şekli de öğretiliyor ama bunu çok güzel yazan da oluyor çok kötü yapan da. Ara tatil bu konuda etki etmedi daha çok etkisi okuma konusunda.

Bunlara ek olarak Osman "Yazma süreci uzun soluklu değerlendirilmesi gereken bir süreç. Ara tatil yazmayı değerlendirebileceğim bir ölçüt değil. Çocuk ara tatilde yazsa da yazmasa da sene sonuna kadar yazmayı çok rahat öğreniyor." ifadeleriyle yazmayı öğrenme sürecinin değerlendirilmesinin uzun soluklu bir iş olduğunu ve bu sebeple de ara tatil gibi kısa bir sürenin yazmayı çok fazla etkilemeyeceğini belirtmektedir. Bunların yanında çalışma grubunda yer alan iki öğretmen, ara tatil sürecinde öğrencilerine yaptırdıkları çalışmalar sayesinde öğrencilerin el becerilerini kaybetmediğini ve bu sayede ara tatilin yazmayı öğrenme sürecine etki etmediğini belirtmişlerdir. Öğretmenlerin bu konudaki ifadeleri aşă̆ıdaki gibidir:

Ası: Yazma konusunda nasıl bıraktıysam öyle devam ettim. Yazma becerisi okumayı kâğıda el becerisi yardımıyla dökmektir. Biz bu süreçte verdiğimiz çalışmalarla el becerisini kaybetmedik. Dolayısıyla yazma sürecinde de bir aksaklık yaşanmadı. Genelde boyama ağırlıklı etkinlikler verdik, çocuk bunlara ödev olarak da bakmadı, eğlenerek yaptı.

Ömer: Yazmayla ilgili ödevlendirme yaptık. O yüzden bir etki yaratmadı. O zamana kadar geldiğimiz seslerin tekrarı, kelime ve cümleler üzerinde durdum.

\section{Ara Tatilin Okuma Yazmayı Öğrenme Sürecine Yansımalarında Etkili Olan Etmenler}

Öğretmenlerle yapılan görüşmeler incelendiğinde ara tatilin öğrencilerin okuma yazmayı öğrenme süreçlerine olumlu veya olumsuz anlamda etki etmesine neden olan birtakım etmenlerin var olduğu görülmüştür. Ara tatilin okuma yazmayı öğrenme sürecine yansımalarında etkili olan etmenler "okul türü", "veli desteği", "öğretmenlerin ara tatile yönelik çalışmaları", "okul öncesi eğitim", "teknolojik imkanlar", "ara tatil öncesi okuma yazma öğretiminde gelinen aşama" ve "ara tatilde oynanan eğitsel oyunlar" kategorileri altında sunulmuştur.

\section{Okul Türü}

Ara tatilin okuma yazmayı olumlu etkilediğini ifade eden öğretmenlerin büyük çoğunluğunun şehir merkezindeki okullarda, olumsuz etki ettiğini ifade eden öğretmenlerin ise hemen hemen tamamının köy okullarında görev yaptığı dikkat çekmektedir. Bu durum ara tatilin köy okullarında ve şehir merkezindeki okullarda farklı etki yaratabileceğini gösterebilir. Nitekim öğretmenlerin ifadeleri de bu durumu destekler niteliktedir. Örneğin Belgin bu durumu "Merkez okul olarak çok etkilediğini düşünmüyorum. Ara tatilin hatta iyi olduğunu düşünüyorum. Ama köy okulunda da çalışmış bir ögrretmen olarak oralarda hafta sonunun bile etki edebileceğini düşünüyorum." ifadeleriyle dile getirmiştir. Buna ek olarak daha önce köy okulunda da çalışmış olan Tülay bu durumu şu ifadelerle desteklemektedir: "Sınıfım iyiydi, ben o yüzden sıkıntı çekmedim. Köy okulunda bunun tam tersi olabiliyor. Çocuk tatil sonrası okula gelmek bile istemeyebiliyor."

\section{Veli Desteği}

Ara tatilin okuma yazmayı öğrenme sürecine etki etmesinde rol oynayan bir başka etmen de veli desteğidir. Örneğin birleştirilmiş sınıflı bir köy okulunda görev yapmakta olan Mehmet bu süreçte velilerle sürekli iletişim halinde olduğunu ve bu durumun ara tatilin olumsuz etkilemesinin önüne geçtiğini belirtmiştir. Bu durum ara tatilde etkili bir veli-öğretmen iş birliğinin okuma yazmaya olası olumsuz etkileri önleyici bir faktör olabileceğine işaret etmektedir. Yine bir köy okulunda öğretmenlik yapan Ayşe ara tatilin çocuğuna karşı ilgili ve ilgili olmayan ailelerin çocukları arasında ne gibi farklı etkilere yol açtığını şu ifadelerle belirtmiştir:

Ayşe: Bu arada dört velim bilinçli, onlar çocuklarını bu süreçte bırakmadı, ilgilendiler. Hiçbir kaybımız olmadı. Diğer öğrenciler evde yattı yattı geldi. Ben tüm çocuklardan ellerindeki Türkçe ders kitaplarını geldiğimiz yere kadar tekrar etmelerini istedim ve velileri arayıp yazdırmalarını istedim. Hikâye kitapları da verdim şimdiye kadar geldiğimiz sesleri içeren. Yazma ödevleri yapılmamış mesela, veliler de bakmamış. Okuma ödevlerini de ebeveynler yapmış çocuk yerine. Tatilden sonra şu an geldiğimiz noktada kayıp yaşamayan öğrencilerle kayıp yaşayanlar arasındaki fark giderek açıldı. 
Buna ek olarak Yasemin öğrencilerinde olumsuz bir durum gözlemediğini ve bunun velilerle ilişkisi olduğunu belirtmiştir. Merve ile Erdal da benzer ifadelerle velinin bu süreçteki önemine dikkat çekmektedirler:

Merve: Bu süreçte çocuklarıla ilgilenemeyen ailelerin çocukları yazma konusunda eksik kaldı. Aile ne kadar ilgilenirse çocuk o kadar istekli oluyor.

Erdal: Tatilden önce etkileriyle ilgili biz korku yaşadık ama tatilden sonra herhangi bir olumsuz etkisini görmedim çünkü evde aileler destekliyor, sürekli okuma yaptırıyor. Merkez okullarda anneler, ablalar, babalar en büyük yardımcımız.

\section{Öğretmenlerin Ara Tatile Yönelik Çalışmaları}

Araştırmadan elde edilen bir diğer bulgu birinci sınıf öğretmenlerinin ara tatil öncesinde öğrencilerinin okuma yazmayı öğrenme sürecine olumsuz etki edeceğinden kaygı duydukları ve bu sebeple ara tatilde öğrencilerinin evde çalışmalarına yönelik bireysel veya zümre olarak çalışma yapma ihtiyacı duydukları yönündedir. Öğretmenler genel olarak yaptıkları bu çalışma ve ödevlendirmelerle öğrencilerinden olumlu dönüt aldıklarını belirtmişlerdir:

Osman: ilk etapta bir kaygı vardı tabi; sesler yetişir mi, çocuklar etkilenir mi diye ama tatilden sonra olumsuz anlamda bir değişim olduğunu fark etmedim. Ara tatilde kayıp olmaması adına ses tekrarı, öğrendiğimiz yere kadarki açık ve kapalı hecelerle ilgili ödevler, okumaları için şiir, tekerleme falan verdim. Çocuğun zaten bu dönemde yapması gereken en önemli şey okuma tekrarı.

Ufuk: Ara tatille ilgili planlama yaptım öncesinde. Tatilde geldiğimiz yere kadarki öğrenmeleri hatırlamalarını sağlayacak etkinlikler hazırladım. Onları bunaltmayacak ve sıkmayacak şekilde. Harfleri birleştirme, hece, kelime ve cümle çalışmaları yapmalarını sağladım. Yazmayı da unutmamaları için geldiğimiz noktaya uygun etkinlikler verdik. Hece ve kelime çalışmaları yaptık. Etkinlikleri sayfalara ayırdık ve okuma ve yazmaya yönelik günde en fazla bir saat olacak şekilde yapmalarını sağladık. Bu sayede olumlu etkisini gördük.

Arzu: Tatilden önce böyle bir kaygımız vardı. Biz arkadaşlarla da konuşmuştuk bunu tam gidiyoruz derken önümüzde boşluk oldu diye. Tatil öğrencilerde biraz gevşemeye neden oldu.

Yusuf: Bizim baştan bir endişemiz oldu. O yüzden biz zümre olarak toplandık ve bir çalışma yapalım dedik. Herkes bir çalışma yaptı, bir araya getirdik. Hızlı okuma metinleri oluşturduk her güne ve her harfe özel.

Bunlara ek olarak ara tatil sürecinde öğrencilerine yönelik plan yapan ve onları ödevlendiren Ahmet ve Büşra yapılan bu çalışmaların etkili olmadığını belirtmiş ve bu durumu ailelerin çocuklarıyla ilgilenmemesine bağlamışlardır. Bu iki öğretmen ara tatil sürecinde ödev ve planlamanın yanında aile desteğine de vurgu yapmışlardır. Ayrıca Büşra ara tatilin sadece dinlenme ve oyun zamanı olarak değerlendirilmesinin birinci sınıf düzeyindeki öğrenciler için yanlış olduğunu belirtmiş ve tatilde ödev vermemenin bu düzeydeki öğrenciler için yanlış bir yaklaşım olacağını belirtmiştir.

\section{Okul Öncesi Eğitim}

Ara tatilin birinci sınıf öğrencilerinin okuma yazmayı öğrenme sürecine etki etmesinde rol oynayan bir diğer etmen okul öncesi eğitimdir. Öğretmenlerden bazıları ana sınıfına giden öğrencilerinin genelde bu tatilden etkilenmediğini hatta onlar için duyuşsal anlamda olumlu olduğunu belirtmişlerdir. Bu öğretmenler okul öncesi eğitimin öğrencilerinin okuma yazmayı öğrenme sürecini kolaylaştırdığı ve hazırbulunuşluklarını artırdığını belirtmişlerdir. Öğretmenlerin bu konudaki ifadeleri şu şekilde örneklendirilebilir:

Erkan: Öğrencilerim ana sınıfından da harfleri öğrenmişlerdi, ben onun rahatlığını yaşadım aslında. Öğrenme süreci bu yüzden çabuk ilerledi. Bu tatil onları sadece motive etti.

Ufuk: Çocuklarımız en az iki yıl ana sınıfı eğitimi görmüşler. Dolayısıyla elleri yatkın, motor becerileri iyi. Biz zorluk çekmedik. Hazırbulunuşluk çok büyük etken. Bu yüzden ara tatil dinlenme fırsatı oldu, iyi oldu öğrencilerim için.

Tülay: Öğretmen için de öğrenci için de güzel bir dinlenme oldu. Kaygım yoktu benim çünkü öğrencilerimin çoğu zaten okuma yazma biliyordu, ana sınıfında öğrenmişler. 


\section{Teknolojik imkanlar}

Çalışmada elde edilen bir diğer bulgu ara tatil sürecinde öğretmenlerin verdikleri ödevlerin ve öğrencilerin çalışmalarının kontrol edilmesinde teknolojinin öğretmenlere destek olduğu yönündedir. Özlem'in "Şu anki teknoloji zaten olumsuzluğa izin vermiyor. Hastalanıp gelmeyen öğrencime bile WhatsApp'tan çalışmaları atıyorum, o zaten nasıl yapılacağını biliyor. Annesini de bilgilendirip evde yaptırıyorum." şeklindeki ifadeleri teknolojinin bu süreçte kullanımının herhangi bir olumsuz yansımaya engel olduğunu çarpıcı bir biçimde ortaya koymuştur. Ayrıca aşağıdaki ifadeler öğretmenlerin ara tatil sürecinde öğrencilerini kontrol amacıyla teknolojiyi nasıl kullandıklarını net bir şekilde ortaya koymaktadır:

Yusuf: Okuma çalışmalarını video şeklinde istedim ve dönüt vermeye çalıştım. Onlar da eksikleri düzeltip tekrar videolarla okuma çalışmalarının düzeltilmiş halini bana gönderdiler. Eğer bu çalışmayı yapmamış olsaydım öğrencilerimin geri kalacağını düşünüyorum. Bir iki çocuk haricinde hepsine ulaştım. Diğerlerinin akıllı telefonu yoktu, onlarla aynı çalışmayı yapamadık bu yüzden geri kaldılar.

Ömer: Velilerle de bu süreçte WhatsApp'tan görüştük. Ne yapmaları gerektiğini anlattım. $O$ yüzden ara tatil olmamıs gibi devam ettik.

Yusuf'un ifadeleri teknolojik gelişmelerin ara tatilin okuma yazmaya etki etmesine engel olduğunu göstermekle birlikte teknolojik araç-gereç eksikliği çeken öğrencilerin de bu süreçte imkansızlıklardan dolayı sınıf düzeyinden geri kaldığını belirtmektedir. Bu durum öğrenciye olumsuz yansırken öğretmenin öğrenciyi toplamaya çalışırken harcadığı enerji açısından da öğretmene iş yükü oluşturmaktadır.

\section{Ara Tatil Öncesi Okuma Yazma Öğretiminde Gelinen Aşama}

Ara tatilin okuma yazmayı öğrenme sürecine etki etmesinde rol oynayan bir diğer etmen ara tatil öncesinde gelinen harf grubudur. Öğretmenler, öğrencilerin okuma yazmayı öğrenme sürecinde ikinci harf grubunu öğrenene kadar sıkıntı çektiklerini sonraki süreçte ise işin mantığını öğrendiklerini ve bu sebeple daha hızı ilerlediklerini belirtmişlerdir. Özlem şu ifadelerle bu durumu açıkça ortaya koymaktadır: "ikinci grup harfleri verene kadar sıkıntı çekiyoruz, sonrasında çocuk sistemi çözüyor ve sadece sesi vermeniz yetiyor. Biz tatilden önce ikinci grubu bitirmiştik, o yüzden çocuklar sorun çekmedi hatta evde başka harfleri öğrenip gelmişler." Ara tatil öncesinde öğrencileriyle ikinci harf grubunu bitiren öğretmenlerin ara tatilin etkisi hususunda olumlu sonuç aldıklarını belirttikleri dikkat çekmektedir. Ufuk'un aşağıdaki ifadeleri de bu durumu desteklemektedir:

Ufuk: Harflerin çoğunu vermiştik, biliyorlardı. Tatilde bunları pekiştirecekleri çalışmalar vererek verimli geçmesini sağladık. Yaptıkları çalışmalardan dolayı unutmadılar öğrendiklerini.

Ara tatil öncesinde birinci harf grubunda olan Arzu ara tatilin okuma yazmayı öğrenme sürecine etkisini şu ifadelerle belirtmiştir:

Arzu: Özellikle kasım ara tatili biraz erken oldu bence. Tam çizgi çalışmaları, harf tanıtımları yaptık hemen arkasına denk geldi. Birinci harf grubunu bitirmemiştik daha ve öğrenciler okuma ve yazmanın mantığını kavramamışlardı.

Arzu'nun ifadeleri tatil öncesinde henüz birinci harf grubunda olmalarından dolayı öğrencilerinin okuma yazma mantığını henüz öğrenmemiş olduğunu ve bu sebeple de ara tatilin olumsuz etki yarattığını vurgulamakta ve tatilin bu sebeple zaman açısından biraz erken verildiğini belirtmektedir. İinci harf grubunu bitiren ve olumlu etki belirten Ufuk da tatilin zamanlamasının bu anlamda iyi olduğunu belirtmektedir. Dolayısıyla ara tatilin etkisinin zamanlamadan ziyade öğretmenlerin tatil öncesinde hangi harf grubunda olduğuyla ilgili değerlendirmelerin yer aldığı söylenebilir.

\section{Ara Tatilde Oynanan Eğitsel Oyunlar}

Son olarak ara tatilde öğrencilerin aileleriyle birlikte oynayabilecekleri eğitsel oyunların önerilmesi bu sürecin okuma yazmayı öğrenmeye olumlu etki etmesine neden olduğu bulgusu elde edilmiştir. Bu husustaki öğretmen görüşlerine Akın'ın aşağıdaki ifadeleri örnek gösterilebilir: 
Akın: Ben birkaç oyun tavsiyesinde bulundum ailelerle oynamalarını istedim. Bazı linkler attım. Eğitici oyunlardı bunlar ve pekiştirmeye yardımcı olabiliyorlar. Çek-oku kartları hazırlamıştım onların resimlerini gönderdim ailelere siz de bu şekilde hazırlayabilirsiniz diye. Çekerek okudukları zaman oyun katılıyor işin içine ve heyecanlı oluyor. Şişe kapaklarına heceler yazdık, hece birleştirme yapabilirsiniz evde dedim. Bu sayede çocuk evde ailesiyle de zaman geçirmiş oluyor.

\section{Tartışma ve Sonuç}

Ara tatilin okumayı öğrenmeye etkisi ile ilgili görüşler incelendiğinde öğretmenlerin, ara tatilin bu sürece etkisini genellikle olumlu gördükleri tespit edilmiştir. Öğretmenlere göre ara tatil öğrencileri duyuşsal anlamda olumlu etkilemiş ve bu durum okumayı öğrenme süreçlerine katkı sağlamıştır. Durlak, Weisserberg, Dymnicki, Taylor ve Schellinger'e (2011) göre duygular, çocukların akademik katılımını, okula bağııığını ve dolayısıyla akademik başarısını etkilemektedir. Öğretmen görüşlerine göre birinci sınıf öğrencileri ara tatilde rahatlamış, okul stresini atmış, dinlenmiş ve bu sebeple de okulu ve sınıf ortamını özleyerek tatil sonrası daha motive bir şekilde okula dönmüşlerdir. Bu durum okumayı öğrenme süreçlerine olumlu yansımış ve okuma süreci daha etkili devam etmiştir. Öğrencilerle daha önce yapılan çalışmalarda okulda verilen araların öğrencilerin sınıf içindeki katılımlarını etkilediği sonucuna varılmışır. Örneğin; Pellegrini, Huberty ve Jones'un (1995) araştırmasına göre öğretmenler, aralardan sonra öğrencilerin daha yüksek ilgi ve daha az sorunlu davranış gösterdiklerini belirtmişlerdir. Dolayısıyla eğitimde verilen araların öğrenci üzerindeki olumlu etkisini ortaya koyan bu çalışma araştırmamızın bulgularını desteklemektedir. Bu durumun genellikle oyun çağında olan ilkokul öğrencilerinin tatillerde oyun için daha fazla zaman bulmalarından kaynaklandığı söylenebilir. Ayrıca bu durum; müfredat yoğunluğundan dolayı öğrencilerin tatillerde dinlenerek ve rahatlayarak okula daha istekli dönmeleri ile açıklanabilir.

Ara tatil öğretmenlere göre, öğrencilerin okula uyumlarını kolaylaştırmış ve bu durumun dolaylı bir şekilde okuma yazmayı öğrenmelerine katkı sağladığı görülmüştür. Bununla birlikte ara tatil sınıf seviyesinin gerisindeki öğrenciler için tekrar fırsatı sunmuş ve bu öğrenciler ara tatil sürecinde eksiklerini kapatma fırsatı bulmuşlardır. Öğretmenler tarafından ara tatilin okumayı öğrenme sürecine birtakım olumsuz etkileri olduğu da belirtilmiştir. Bu etkiler genel anlamda tatilden kaynaklı rahatlama ve rehavete kapılma gibi etmenlerle ilişkilidir. Bazı öğrenciler tatil sonrası gevşeme ve isteksizlik yaşamış ve öğretmenler tatil dönüşü sınıflarını toparlamakta zorluk çekmişlerdir. Bu durum okuma yazmayı öğrenme sürecini de olumsuz etkilemiş ve süreci yavaşlatmıştır. Erbasan ve Erbasan'ın (2020) çalışmasında öğrencilerin ilk okuma yazmaya yönelik ilgilerinin düşük olduğu ve derslerden çabuk sıkıldıkları belirlenmiştir. Tatilin rehavetiyle başa çıkmaya çalışan öğretmenler tatil sonrası daha fazla çaba sarf etmek durumunda kalmışlardır. Ayrıca ara tatil bazı öğrencilerde okuma yazma bağlamında unutmalara neden olmuş ve öğretmenler tatil dönüşü başa dönmek zorunda kalarak okuma yazma sürecini baştan ele almışlardır.

Öğretmenlere göre, ara tatilin yazmayı öğrenme sürecine etkisi okuma gibi net değildir. Öğretmenlerin büyük çoğunluğu yazmanın el becerisi ile ilgili olduğunu ve uzun soluklu bir değerlendirmeye ihtiyaç olduğunu düşünmekte ve bir haftalık sürecin yazmayı öğrenme sürecine çok etki etmediğini ifade etmektedirler. Öğretmenler tarafından ara tatil sürecinde yaptırılan çalışmalar öğrencilerin yazmada etkili olan psikomotor becerilerinin ve dolayısıyla yazma sürecinin olumsuz etkilenmemesini sağlamıştır. Cameron, Cottone, Murrah ve Grissmer (2016), 5 yaşında güçlü motor becerilerine sahip çocukların ileriki yaşlarda zayıf motor becerileri olan akranlarına göre okuma ve matematikte daha iyi performans gösterdiğini bulmuşlardır. Dolayısıyla araştırmanın bu çalışmayı destekler sonuçlar ortaya koyduğu söylenebilir. Ara tatilin öğrenciler üzerindeki etkisi öğretmenler tarafından yine duyuşsal boyutta görülmüş ve bu durumun yazmayı öğrenme süreçlerine olumlu şekilde yansıdığı belirtilmiştir. Ara tatil öğrencilere dinlenme imkânı sunmuş ve öğrenciler tatil dönüşü yazmaya daha yüksek bir motivasyonla devam etmişlerdir. Öğrencilerin yazarken sıkılmalarıysa yazmayı öğrenme sürecini olumsuz etkilemektedir. Yazmak sıklıkla çocuklar tarafından öğretmene ne öğrendiklerini gösterdikleri bir okul etkinliği olarak görülmektedir (Wray, 1993). El becerisine dayalı bu etkinlik, öğrenciler tarafından sıkıcı görülebilmektedir. Guay, Ratelle ve Chanal'a (2008) göre motivasyon ve duyuşsal faktörler çocukların akademik becerilerini etkilemektedir. 
Takımcıgil Özcan (2014) ve Hidi ve Boscolo'nun (2006) araştırma sonuçları da yazmaya yönelik yüksek motivasyona sahip olan öğrencilerin yazma becerilerinin de yüksek düzeyde olduğunu göstermektedir. Dolayısıyla öğrencilerin yazmaktan sıkılmalarında motivasyonel süreçlerin etkili olduğu söylenebilir. Öğrencilerin yazmaya istekli olmaları, yazmaktan zevk almaları ve sıkılmamaları için ilgi çekici buldukları konularda yazma çalışmaları yapmaları önem arz etmektedir. Öte yandan öğretmenler, bazı öğrencilerin ara tatilde veli desteği ile yeni harfler öğrendiğini ve bunları yazabildiklerini belirtmişlerdir. Öğretmenlerin ara tatilin öğrencilerin yazmayı öğrenme süreçlerine etkisi ile ilgili ortaya koydukları görüşlerin farkı olması öğrencilerin yazmaya yönelik bilişsel, duyuşsal ve psikomotor hazır oluşlarıyla açıklanabilir.

Okuma ve yazma becerilerinin birbirinin gelişimini etkilemektedir (Andersen ve diğerleri, 2018). Bu çalışmada da okumayı öğrenme sürecinde olumsuz etki görülen öğrencilerin yazma konusunda da sorun yaşadığı sonucuna ulaşılmıştır. Bu sonuçlar yazmayı öğrenme sürecinde öğretmen kontrolünün önemli olduğunu göstermektedir. Kamhi ve Catts'e (2012) göre yazı dili ve konuşma dili aynı şekilde edinilmediğinden çocukların okuma ve yazmayı geliştirmek için kaliteli eğitime ve bireysel desteğe ihtiyacı vardır (akt. Sandberg, Hellblom-Thibllin ve Garpelin, 2015). Dolayısıyla öğretmenlerin ara tatil sürecinde öğrencilerinin yazmayı öğrenme sürecini kontrol edememelerinin süreci olumsuz etkilediği söylenebilir.

Yazmayı öğrenme sürecine bir başka olumsuz yansıma da ara tatil sürecindeki tekrar eksikliğidir. Ayrıca ara tatilin bakarak yazma aşamasındaki öğrencilere olumsuz etkisinin olmadığı fakat dikte çalışmalarını sekteye uğrattığı sonucuna ulaşımıştır. Öğretmenler bu süreçte bir günün bile büyük etki yaratabileceğini dolayısıyla dokuz günlük ara tatilin uzun bir süreç olduğunu belirtmişlerdir. Bu durum okuma yazma öğrenen öğrencilerin bulunduğu gelişim düzeyi ve dikte çalışmalarının bakarak yazma çalışmalarına göre daha fazla duyu ve beceriye hitap etmesiyle açıklanabilir.

Araştırmada ara tatilin öğrencilerin okuma yazmayı öğrenme süreçlerine etki etmesinde birtakım etmenlerin rol oynadığı sonucuna ulaşıımıştır. Ara tatilin köy okullarında ve merkezi okullarda öğrenim gören öğrencilerin okuma yazmayı öğrenme süreçleri üzerinde farklı etkiler yarattığı görülmektedir. Öğretmenlere göre köylerdeki sosyoekonomik yapının, aile yapısının ve daha rahat bir oyun ortamının olmasının çocukları ara tatil sürecinde okuma yazma sürecinden uzaklaştırdığı söylenebilir. Köy okullarında görev yapan bazı öğretmenler ise karşılaştıkları problemleri aile desteği ile çözdüklerini belirtmişlerdir.

Ara tatil sürecindeki veli-öğretmen iş birliği ara tatilin öğrencilerin okuma yazma sürecine etkisinin pozitif yönde olmasını sağlamıştır. Bununla birlikte yetersiz aile desteği ise ara tatilin yazmayı öğrenme sürecini olumsuz etkilemesine neden olan bir etmendir. Bu durumun sadece ara tatil ile ilişkilendirilmesi objektif bir yaklaşım olmayabilir zira ara tatil süreci dışında da velilerin yeterince destek olmamaları, öğretmenlerle yeterince iş birliği yapmamaları sorununun var olduğu Erbasan ve Erbasan'ın (2020) çalışmalarıyla desteklenmiştir. Menheere ve Hooge (2010) da çalışmalarında, ebeveyn katıımının çocukların okul başarısını ve öğrenme motivasyonunu pozitif yönde etkilediğini ortaya koymuşlardır. Bu durum bütünsel bir nitelik taşıyan okuma yazma öğrenme sürecinin okul dışında da desteklenmesi gerektiğine işaret etmektedir.

Araştırma sonuçları öğretmenlerin yeni bir uygulama olması nedeniyle ara tatil süreci ile ilgili kaygı duyduklarını, bu nedenle bireysel ve zümre olarak birtakım planlama ve ödevlendirme çalışmaları yaptıklarını göstermektedir. Bu etkinlikler çoğunlukla olumlu dönüt sağlamış ve ara tatilde öğrencilerin hem dinlenmesine hem de bu süreçten geri kalmamalarına olanak tanımıştır. Öğretmenlerin, bu yaklaşımı okuma yazma öğrenme sürecini okul dışına taşıma amacıyla benimsedikleri söylenebilir. Ancak ödev öğrenciler tarafından genellikle tercih edilmeyen bir okul aktivitesidir. Duru ve Çöğmen (2017) öğrencilerin ödevden hoşlanmama sebeplerini; ödevi sevmeme, sıkıcı bulma, yetersiz hissetme, zorluk, zaman alması, elin yorulması, çok yazmayı gerektirmesi şeklinde sıralamışlardır. Öğrencilerin ödevlere karşı bu yaklaşımı ise ödevleri bir okul aktivitesi olarak görmeleri, tatillerde de herhangi bir okul aktivitesi yapmak istememeleri ile açıklanabilir.

Ara tatil sürecinde öğretmenlerin aile ile birlikte oynanabilen eğitsel oyunları teşvik etmeleri, bu süreçte hem öğrencilerin aileleri ile birlikte kaliteli zaman geçirmelerine olanak tanımış hem de 
okuma yazmayı öğrenme süreçlerini desteklemiştir. Eğitsel oyunlar; çocukların zevk alarak öğrenmelerini ve öğrendiklerini yaşantılara dönüştürmelerini sağlayarak (Bektaş, 2020), yaparak yaşayarak öğrenme imkanıyla aktif bir öğrenme süreci (Yıldız ve Şimşek, 2020) sunar. Bu araştırmaların çalışmayı destekleyici sonuçlar ortaya koyduğu söylenebilir. Bu sonuç eğitsel oyunların, oyun çağında olan çocukların ilgi ve ihtiyaçlarına hitap etmesiyle açıklanabilir.

Ara tatilin öğrencilerin okuma yazma sürecine etki etmesine neden olan bir diğer etmen okul öncesi eğitimdir. Sınıfında okul öncesi öğrenim gören öğrencilerin çoğunlukta olduğu öğretmenler ara tatil süreci ve sonrasında herhangi bir sorun yaşamamışlardır. Öğretmenler öğrencilerinin çoğunun zaten birinci sınıfa gelirken okuma ve yazma bildiklerini belirtmişlerdir. Okul öncesi eğitim öğrencilerin okuma yazma öğrenme sürecini kolaylaştırmış ve öğrenciler birinci sınıfa hazırbulunuşlukları yüksek bir şekilde gelmişlerdir. Sandberg, Hellblom-Thibblin ve Garpelin'in (2015) çalışması da okul öncesi eğitim alan çocukların akademik olduğu kadar sosyal anlamda da olumlu etkilendiklerini ortaya koyması açısından bu sonucu desteklemektedir. Okul öncesi eğitim alan çocukların almayan çocuklara oranla ilköğretime hazırbulunuşluk ve akademik başarı açısından daha avantajlı oldukları Cinkılıç (2009) tarafından da ortaya koyulmuştur. Bu sonuç, okul öncesi eğitimde yapılan okuma yazmaya hazırlık etkinlikleriyle açıklanabilir.

Araştırmada ulaşılan bir diğer sonuç öğretmenler ve veliler tarafından teknolojinin etkin kullanımının ara tatilin okuma yazmayı öğrenme sürecine olumsuz etkilerini engelleyebileceğidir. Çalışma şunu göstermektedir ki bazı öğretmenler bu süreçte öğrencilerinin okuma ve yazma ödevlerini kontrol ederken ve velilerle iletişim kurarken teknolojiyi etkin bir biçimde kullanmış ve bu durum öğrencilere pozitif yönde yansımıştır. Napratilora, Lisa ve Bangsawan (2020) araştırmalarında WhatsApp kullanımının öğrencilerin motivasyonunu artırdığı, sınıf dışında kullanılabilmesi açısından pratik olduğu ve öğrenmeyi olumlu etkilediğini bulmuşlardır. Bu araştırmanın katılımcılarından biri de teknolojik araç-gereç eksiği olan öğrencilerinin sınıfın geri kalanıyla yürütülen çalışmalara katılamadığını ve bu nedenle geri kaldığını belirtmiştir. Bu durum eğitimde fırsat eşitliğini gündeme getirmekte ve teknolojik araç-gereç eksikliği yaşayan öğrencilerde okuma yazma süreci açısından olumsuz yansımaların görülme ihtimalini artırmaktadır. Fırsat eşitsizliğinin sebeplerini araştıran çalışmalar teknolojik altyapıya sahip materyallerin giderek önem kazanmasına vurgu yaparak sosyoekonomik gelişmişlik düzeylerini dengelemenin bu noktada son derece önemli olduğu sonucuna işaret etmektedir (İnan ve Demir, 2018).

Okuma yazma öğretimi sürecinde ara tatil öncesinde gelinen aşama bu süreci etkileyen bir diğer etmendir. Öğretmenler okuma yazma mantığını anlama açısından ikinci harf grubunu önemli görmekte ve ikinci harf grubunun bitirilmesine kadar geçen süreçte öğrencilerin süreci ancak anladıklarını belirtmektedirler. Ara tatil öncesi ikinci harf grubuna gelememiş olan öğretmenler ara tatilin bu süreci engellediğini belirtmişlerdir. Ayrıca öğretmenler bu sebeple tatilin zamanını erken bulmuş ve daha sonra verilecek bir tatilin daha etkili olabileceğini belirtmişlerdir. Bir haftalık ara tatil süre açısından öğretmenlerce uygun görülmekle birlikte tatilin zamanlaması üzerinde tekrar düşünülmesi gerektiği vurgulanmıştır. Tatil öncesi ikinci harf grubunu da öğrencilerine tanıtan öğretmenler ara tatil sürecinin olumsuz herhangi bir yansımasını görmemiş ve hatta bazıları olumlu olarak değerlendirmiştir. Ara tatilin dönemin tam ortasına gelmesinin diğer sınıf gruplarında olumlu karşılanabilecekken birinci sınıf düzeyinde bu şekilde bir olumsuzluğa neden olduğu ifade edilebilir.

Sonuç olarak ara tatilin okuma yazma öğrenme sürecine olumlu ve olumsuz yansımalarının olduğu, bununla birlikte özellikle yazmayı öğrenme sürecinde önemli bir etkiye sahip olmadığı araştırmada elde edilen temel sonuçlardır. Ara tatilin okuma yazma öğrenme sürecine etkisinin olumlu veya olumsuz anlamda gelişmesinde; okul türü, veli desteği, öğretmenlerin ara tatile yönelik çalışmaları, okul öncesi eğitim, teknolojik imkanlar, ara tatil öncesi okuma yazma öğretiminde gelinen aşama ve ara tatilde oynanan eğitsel oyunlar gibi etmenlerin etkili olduğu da bu araştırmanın önemli bir sonucudur. Buradan hareketle; ara tatilin zamanlamasının birinci sınıf öğrencilerinin ihtiyaçları göz önünde bulundurularak sınıf düzeyi özelinde tekrardan ele alınması gerektiği düşünülmektedir. Öğretmenlerin öğrencilerini ara tatilde destekleyebilecekleri çalışmalar konusunda hizmet içi eğitimlerle, velilerin ise teknoloji kullanımı ve tatillerde oynanabilecek eğitsel oyunlarla ilgili seminerlerle bilgilendirilmeleri önerilmektedir. Bununla birlikte okul öncesi eğitimin ülke çapında 
yaygınlaştırıması önerilmektedir. Ayrıca araştırmacılara; ara tatilin birinci sınıf öğrencilerinin okuma ve yazma performanslarına etkisinin istatistiksel analizlerle ortaya koyulacağı nicel araştırmaların yapılması ve farklı bölgelerden, farklı branşlardan katılımcılarla araştırmalar yapılması önerilmektedir. Ek olarak ara tatilin diğer sınıf düzeyleri ve dersler bağlamında etkilerinin ortaya koyulacağı araştırmaların yapılması, bu etkilerin çok boyutlu olarak değerlendirilebilmesi açısından önemli görülmektedir.

\section{Araştırma ve Yayın Etiği}

Bu çalışmada "Yükseköğretim Kurumları Bilimsel Araştırma ve Yayın Etiği Yönergesi" kapsamında uyulması belirtilen tüm kurallara uyulmuştur. Yönergenin ikinci bölümü olan "Bilimsel Araştırma ve Yayın Etiğine Aykırı Eylemler" başlığı altında belirtilen eylemlerden hiçbiri gerçekleştirilmemiştir.

\section{Etik Kurul İzni}

Kurul adı $=$ Ondokuz Mayıs Üniversitesi Sosyal ve Beşerî Bilimler Etik Kurulu

Karar tarihi $=29.11 .2019$

Belge sayı numarası $=2019-381$

\section{Yazarların Katkı Oranı}

Araştırmanın tüm yazarları çalışmaya eşit oranda katkı (\%25) sağlamıştır.

\section{Çıkar Çatışması}

Araştırma öncesi, araştırma süreci ve araştırma sonrasında araştırmacılar arasında çıkar çatışmasına neden olabilecek herhangi bir durum bulunmamaktadır.

Akyol, H. (2011). Türkçe öğretimi. Ankara Pegem Akademi.

Akyol, H. (2020). Türkçe ilk okuma ve yazma öğretimi. Ankara: Pegem Akademi.

Andersen, S. C., Christensen, M. V., Nielsen, H. S., Thomsen, M. K., Osterbye, T., \& Rowe, M. L. (2018). How reading and writing support each other across a school year in primary school children. Contemporary Educational Psychology, 55, 129-138. https://doi.org/10.1016/j.cedpsych.2018.09.005

Anras, B. (2019). Mesleğe yeni başlayan sınıf öğretmenleri ile tecrübeli sınıf öğretmenlerinin ilkokuma yazma öğretiminde karşılaştıkları sorunların karşılaştııılması (Mardin ili örneği) (Yayımlanmamış yüksek lisans tezi). Gazi Üniversitesi Eğitim Bilimleri Enstitüsü, Ankara.

Arı, A. (2005). ilköğretim okulu öğrencilerinin yaz tatilindeki öğrenme kayıpları (Yayımlanmamış doktora tezi). Gazi Üniversitesi Eğitim Bilimleri Enstitüsü, Ankara.

Arıcl, A. F. (2018). Okuma eğitimi. Ankara: Pegem Akademi.

Ary, D., Cheser Jaobs, L., Sorensen Irvine, C. K., \& Walker, D. A. (2019). Introduction to research in education (10th edition). Boston: Cengage.

Aslan, F. ve Altunova, N. (2019). Birinci sınıf Türkçe (ilkokuma yazma) öğretim programının değerlendirilmesi. Adıyaman Üniversitesi Sosyal Bilimler Enstitüsü Dergisi, 12(32), 31-75. https://doi.org/10.14520/adyusbd.490598

Babayiğit, Ö. (2016). Illk okuma yazma öğretiminde oyunla öğretim yöntemi uygulamaları (Yayımlanmamış doktora tezi). Anadolu Üniversitesi Eğitim Bilimleri Enstitüsü, Eskişehir.

Baş, Ö. (2006). Ses temelli cümle yöntemi ve bitişik eğik yazıyla okuma yazma öğretiminde alternatif harf sıralaması. Uluslararası Sınıf Öğretmenliği Kongresi Bildiri Kitabı (ss. 215-224). Ankara: Kök Yayıncılık.

Bektaş, S. (2020). Illk okuma yazma öğretiminde eğitsel oyunların 1. sınıf öğrencilerinin okuma becerilerine olan etkisinin incelenmesi (Yayımlanmamış yüksek lisans tezi). Sakarya Üniversitesi Eğitim Bilimleri Enstitüsü, Sakarya. 
Burç, G. ve Karakuyu, A. (2020). Sınıf öğretmenlerinin dönem içerisindeki ilk kez uygulanan ara tatil uygulaması hakkındaki görüşleri. Uluslararası Sosyal Araştırmalar Dergisi, 13(70), 746-752. http://dx.doi.org/10.17719/jisr.2020.4132

Cameron, C.E., Cottone, E.A., Murrah, W.M., \& Grissmer, D.W. (2016). How are motor skills linked to children's school performance and academic achivement? Child Development Perspectives, 10(2). https://doi.org/10.1111/cdep.12168

Cinkılıç, H. (2009). Okul öncesi eğitiminin ilköğretim 1.sını öğrencilerinin okul olgunluğuna etkisinin incelenmesi (Yayınlanmamış yüksek lisans tezi). Selçuk Üniversitesi Sosyal Bilimler Enstitüsü, Konya.

Creswell, J. W. (2011). Designing and conducting mixed methods research (2nd ed.). Thousand Oaks, CA: Sage.

Dedeli, S. (2008). Sınıf öğretmenliği son sınıf öğrencilerinin yapılandırmacı yaklaşıma göre ses temelli cümle yöntemiyle ilkokuma ve yazma öğretimi konusunda yeterlilik düzeylerine ilişkin bir araştırma (Yayımlanmamış yüksek lisans tezi). Dokuz Eylül Üniversitesi Eğitim Bilimleri Enstitüsü, İzmir.

Doğan, A. (2020). Sınıf Öğretmenlerinin ara tatillere yönelik görüşleri. O. Köse ve Y. Ulutürk Sakarya (Ed.), Sosyal Bilimlerde Yeni Araştırmalar-III (ss. 241-252). Ankara: Berikan Yayınevi.

Durlak, J. A., Weissberg, R. P., Dymnicki, A. B., Taylor, R. D., \& Schellinger, K. B. (2011). The impact of enhancing students' social and emitoinal learning: a meta-analysis of school-based universal interventions. Society for Research in Child Development, 82(1). https://doi.org/10.1111/j.1467-8624.2010.01564

Durna, Y. (2014). 2012-2013 eğitim-öğretim yılında 60-66 ay arasında ve 66. ay üzerinde okula kayıt yaptıran 1.sını öğrencilerinin ilk okuma yazma dersi öğretim programı kazanımları ile okul yaşantıları sürecinin performans yönünden öğretmen görüşlerine dayalı olarak karşılaştırılması (Erzincan örneği) (Yayımlanmamış yüksek lisans tezi). Erzincan Üniversitesi Sosyal Bilimler Enstitüsü, Erzincan.

Duru, S. ve Çöğmen, S. (2017). İlkokul ve ortaokul öğrencileri ve velilerin ev ödevlerine yönelik görüşleri. Illköğretim Online, 16(1), 354-365. http://dx.doi.org/10.17051/io.2017.76577

Ekici Calın, T. (2019). Sınıf öğretmenlerinin ilk okuma yazma öğretimine ilişkin görüşleri (Yayımlanmamış yüksek lisans tezi). Hacettepe Üniversitesi Eğitim Bilimleri Enstitüsü, Ankara.

Erbasan, Ö. ve Erbasan, Ü. (2020). Sınıf öğretmenlerinin ilk okuma yazma öğretimi sürecinde karşılaştığı sorunlar. Ana Dili Eğitimi Dergisi, 8(1), 113-125. https://doi.org/10.16916/aded.628267

Gözüküçük, M. (2017). Ses esası ilk okuma yazma öğretimi ve yapılandırmacılık. F. Susar Kırmızı ve E. Ünal (Ed.), ilk okuma yazma öğretimi (ss. 1-33). Ankara: Anı Yayıncılık.

Graham, S., Gillespie, A., \& McKeown, D. (2013). Writing: Importance, development, and instruction. Reading and Writing, 26(1), 1-15. https://doi.org/10.1007/s11145-012-9395-2

Guay, F., Ratelle, C. F., \& Chanal, J. (2008). Optimal learning in optimal contexts: The role of selfdetermination theory in education. Canadian Pyschology, 49(3), 233-240. https://doi.org/10.1037/a0012758

Güneş, F. (2009). Hızlı okuma ve anlamı yapılandırma. Ankara: Nobel Yayınları.

Güneş, F. (2010). Ninnilerin çocukların dil ve zihinsel gelişimine etkisi. Zeitschrift für die Welt der Türken, 2(3), 27-38. Erişim adresi: http://dieweltdertuerken.org/index.php/ZfWT/article/view/183/f_gunes

Hacker, D. J., Keener, M. C., \& Kircher, J. C. (2009). Writing is applied metacognition. D. J. Hacker, J. Dunlosky ve A. C. Graesser (Ed.), Handbook of metacognition in education (ss. 154-172). New York: Routledge.

Hidi, S., \& Boscolo, P. (2006). Motivation and Writing. Macarthur, C., Graham, S., \& Fitzgerald, J., (Ed.), Handbook of Writing Research (Chapter 10). New York: The Guilford Press.

İnan, M. ve Demir, M. (2018). Eğitimde fırsat eşitliği ve kamu politikaları: Türkiye üzerine bir değerlendirme. Ankara Hacı Bayram Veli Üniversitesi iktisadi ve Idari Bilimler Fakültesi 
Dergisi, 20(2), 337-359. Erişim adresi https://dergipark.org.tr/tr/download/articlefile/562717

İnce Samur, A. Ö. (2017). Okuma kültürü edinme sürecinde "ilkokul dönemi 6-10Yaş)". Ankara Üniversitesi Eğitim Bilimleri Fakültesi Dergisi, 50 (1), 209-230. Erişim adresi https://dergipark.org.tr/tr/download/article-file/508578

Kabaş, i. (2020). Sınıf öğretmenlerinin ilk okuma yazma öğretimi öz yeterlik algıları ile okuma yazma ögretim programına bağlıııları (Yayımlanmamış yüksek lisans tezi). Bolu Abant İzzet Baysal Üniversitesi Eğitim Bilimleri Enstitüsü, Bolu.

Karadağ, R. (2017). Yazma becerisinin geliştirilmesi. F. Susar Kırmızı ve E. Ünal (Ed.), Illk okuma yazma öğretimi (ss. 35-77). Ankara: Anı Yayıncılık.

Karasar, N. (2015). Bilimsel araştırma yöntemi: Kavramlar, ilkeler, teknikler (Gözden geçirilmiş/genişletilmiş 28. baskı). Ankara: Nobel Yayıncılık.

Karatay, H. (2018). Okuma eğitimi kuram ve uygulama. Ankara: Pegem Akademi.

Kasten, W. C., \& Yıldırım, K. (2013). Okuma ve yazma öğretimi: Tek başıma öğrenemem ki. Ankara: Pegem Akademi.

Kaya, S. (2020). Türk eğitim sisteminde yeni dönem: Ara tatil. Turkish Studies - Education, 15(2), 10491059. https://dx.doi.org/10.29228/TurkishStudies.40272

Kurudayıoğlu, M. (2011). Zihinsel ve fiziksel bir süreç olarak okuma. Gazi Eğitim Fakültesi Dergisi, 31(1), 15-29. Erişim adresi http://www.gefad.gazi.edu.tr/tr/download/article-file/76991

Lodico, M. G., Spaulding, D. T., \& Voegtle, K. H. (2010). Methods in educational research: From theory to practice. San Francisco, CA: Jossey-Bass.

Menheere, A., \& Hooge, E. H. (2010). Parental involment in children's education: A review study about the effects of parental involment on children's school education with a focus on the position of illiterate parents. Journal of the European Teacher Education Network (JETEN), 6, 144-157.

Merriam, S. B. (2013). Nitel araştırma: Desen ve uygulama için bir rehber (S. Turan, çev.). Ankara: Nobel Yayınevi.

Miles, M. B., \& Huberman, A. M. (1994). Qualitative data analysis: An expanded Sourcebook (2 ${ }^{\text {nd }}$ ed.). Thousand Oaks, CA: SAGE.

Millî Eğitim Bakanlığı. (2019). Türkçe dersi öğretim programı. Erişim adresi https://mufredat.meb.gov.tr/ProgramDetay.aspx?PID=663

Napratilora, M., Lisa, H., \& Bangsawan, I. (2020). Using WhatsApp as a learning media in teaching reading. Mitra PGMI: Jurnal Kependidikan MI, 6(2), 116-125. https://doi.org/10.4108/eai.274-2019.2286815

Obalar, S. (2009). Illköğretim birinci sınıf öğrencilerinin ilk okuma yazma becerileri ile sosyal duygusal uyum ve zekâ düzeyleri arasındaki ilişkinin incelenmesi (Yayımlanmamış doktora tezi). Marmara Üniversitesi Eğitim Bilimleri Enstitüsü, i̇stanbul.

Park, H. (2008). Home literacy environments and children's reading performance: A comparative study of 25 countries. Educational Research and Evaluation, 14(6), 489-505. https://doi.org/10.1080/13803610802576734

Patton, M. Q. (2014). Nitel Araştırma ve Değerlendirme Yöntemleri. (M. Bütün ve S. B. Demir Çev.) Ankara: Pegem Akademi.

Pellegrini, A. D., Huberty, P. D., \& Jones, I. (1995). The effects of recess timing on children's playground and classroom behaviors. American Educational Research Journal, 32, 845-864. https://doi.org/10.2307/1163338

Pickard, A. (2012). Research methods in information. London: Facet.

Resmî Gazete (2019). 30827 sayılı Millî Eğitim Bakanlığı okul öncesi eğitim ve ilköğretim kurumları yönetmeliğinde değişiklik yapılmasına dair yönetmelik. Erişim adresi https://www.resmigazete.gov.tr/eskiler/2019/07/20190710-6.htm

Saldana, J. (2019). Nitel araştırmacılar için kodlama el kitabı (S. Şad Ed.). Ankara: Pegem Akademi. 
Sandberg, G., Hellblom-Thibllin, T., \& Garpelin, A. (2015). Teachers' perspective on how to promote children's learning in reading and writing. European Journel of Special Needs Education, 30(4), 505-517. https://doi.org/10.1080/08856257.2015.1046738

Silverman, D. (2018). Nitel verileri yorumlama (E. Dinç Çev.). Ankara: Pegem Akademi.

Şahin, A. (2004). Ilköğretimde tatil sonrası öğrenme kayıpları (Yayımlanmamış yüksek lisans tezi). Afyon Kocatepe Üniversitesi Sosyal Bilimler Enstitüsü, Afyonkarahisar.

Şen, E. U. (2009). Yapılandırmacı yaklaşım temelli yeni ilköğretim programı kılavuzluğunda gerçekleştirilen öğretim etkinlikleri sonrası yaz tatili öğrenme kayıpları (Yayımlanmamış yüksek lisans tezi). Ondokuz Mayıs Üniversitesi Sosyal Bilimler Enstitüsü, Samsun.

Takımcıgil Özcan, S. (2014). Ilkokul 4. sınıf öğrencilerinin yazma motivasyonları ile hikâye yazma becerilerinin değerlendirilmesi (Yayımlanmamış yüksek lisans tezi). Sakarya Üniversitesi Eğitim Bilimleri Enstitüsü, Sakarya.

Tosunoğlu, M. (2006). İlkokuma ve yazma öğretim yöntemiyle ilgili öğretmen görüşleri. Türk Dili Araştırmaları Yıllığı-Belleten, 49(1), 195-222. Erişim adresi https://dergipark.org.tr/tr/download/article-file/721452

Tutal, Ö. ve Oral, B. (2015). İlk okuma-yazma öğrenmede okula başlama yaşının okuma-yazma başarısına etkisi. Dicle Üniversitesi Ziya Gökalp Eğitim Fakültesi Dergisi, 24, 96-121. Erişim adresi https://dergipark.org.tr/en/pub/zgefd/issue/47937/606407

Wray, D. (1993). What do children think about writing? Educational Review, 45(1), 67-77. https://doi.org/10.1080/0013191930450106

Yıldııı, A. ve Şimşek, H. (2018). Sosyal Bilimlerde Nitel Araştırma Yöntemleri (11. baskı). Ankara: Seçkin Yayınevi.

Yıldız, E. ve Şimşek, Ü. (2020). Eğitsel oyun, okuma-yazma-oyun ve okuma-yazma uygulama yöntemlerinin öğrenme problemlerini gidermedeki etkisi. Uludağ Üniversitesi Eğitim Fakültesi Dergisi, 33(3), 715-748. https://doi.org/10.19171/uefad.659040

\section{Extended Abstract}

\section{Introduction}

Only students who know how to read and write can use language correctly and improve it. Reading is a process in which we transmit signs and symbols to the brain through the senses of hearing and sight and we interpret those stimuli and attribute meaning to them (Kurudayıoğlu, 2011). Writing is a process in which we generate thoughts through target-oriented metacognitive monitoring and control and transform them into symbols (Hacker, Keener, \& Kircher, 2009). These two linguistic skills have an important place in life. Students acquire them in the first grade of elementary school.

Literacy skills are affected by several factors such as parental support, parents' literacy level, and socioeconomic status. For the first time in the 2019-2020 academic year, the Turkish Ministry of Education shortened the summer vacation by two weeks and gave two one-week midterm breaks in November and April. This study investigated what teachers thought about the effect of those midterm breaks on first graders' literacy skills. Only a handful of studies looked into the effect of midterm breaks on students. Those studies address what students (Kaya, 2020) and elementary school teachers (Burç \& Karakuyu, 2020; Doğan, 2020) think about the midterm breaks. This study is the first one to examine the reflections of the midterm breaks on students' literacy learning process.

\section{Method}

This study employed the basic qualitative research design to investigate teachers' views of the effect of the midterm breaks on students' literacy skills. The basic qualitative research design was used to make sense of a phenomenon or process from the perspective of people who experience it (Ary, Cheser Jaobs, Sorensen Irvine, \& Walker, 2019). This design helps researchers understand "multiple or individual realities" about an event or situation (Pickard, 2012). The sample consisted of 24 classroom teachers from elementary schools in the Atakum district of the province of Samsun in the 2019-2020 academic year. One teacher from each primary school was included in the sample 
using maximum variation sampling. All schools were affiliated with the District National Education Directorate. The sample was diverse in terms of gender, work experience, and type of school. Data were collected through a semi-structured interview form developed by the researchers. The data were analyzed by doing content analysis. The researchers transformed the data into codes and themes. Afterward, three field experts were asked to check the codes and themes for validity, reliability, and diversity.

\section{Result and Discussion}

The data were evaluated under three main headings: (1) the effects of midterm breaks on students' reading skills, (2) the effects of midterm breaks on students' writing skills, and (3) the factors that played a role on the effects of midterm breaks on literacy skills. According to the participants, the breaks had affective effects on students' literacy skills. However, the participants thought that the breaks had a positive effect on students' reading skills. Students had opportunities to rest, become refreshed, and spend quality time with their parents during the breaks and that made them more motivated to go to school. According to the participants, the breaks allowed the students to adapt to school faster, go over what they had learned, and fill in gaps in terms of knowledge, and this way they contributed to their reading skills. The participants also reported that some students became alienated from school, went into vacation mode, and experienced losses in the reading skills they had acquired at school during the midterm breaks.

The participants, in general, believed that the midterm breaks had neither positive nor negative effects on students' writing skills. According to the participants, writing is a dexterity-based skill whose effects should be assessed in the long term. Most participants stated that they gave homework assignments to their students during the midterm breaks so that they would not lose their dexterity in writing. According to some participants, some students considered the writing process tiring or dull. Those students found a chance to have some rest during the breaks and return to school having rested, which made them more motivated to learn how to write. Some participants stressed that their students learned new letters from their parents during those breaks. According to some participants, the midterm breaks prevented students from going over what they had learned and this hampered their writing skills. Those participants also stated that they realized during postmidterm break dictation activities that their students had lost their writing skills during the midterm breaks.

The results showed that some factors played a key role regarding the effects of the breaks on students' basic literacy skills. The first one is the location of the school (village, town, or city) and the technological resources students or their families have. Participants working at village schools emphasized the negative effects of midterm breaks. Participants working at schools in the city center underlined the positive effects of the breaks. Those working at schools in the city center and villages supported this view.

Participants stated that they gave the students homework assignments during midterm breaks because they were concerned about the adverse effects of the breaks on their literacy skills. They believed that the homework assignments prevented the adverse effects of the breaks. Moreover, teacher-parent interaction and collaboration during the breaks and preschool education experience contributed positively to students' literacy skills during midterm breaks. 